Miscellanea Anthropologica et Sociologica 2014, 15 (2): 15-32

Sigurjón B. Hafsteinsson ${ }^{1}$

Tinna Grétarsdóttir ${ }^{2}$

Arnar Árnason ${ }^{3}$

\title{
The uses and abuses of the past: cultural rhetoric and the unmaking of a moral universe
}

It is well established ethnographically that history is a particularly important and celebrated aspect of Icelandic identity. Paraphrasing Hastrup, it could be argued that Icelandic culture is a culture of the past. The collapse in Iceland in 2008 problematised this valorisation of history. In this paper we draw on Carrithers' ideas of cultural rhetoric to analyse how Icelanders made sense of the collapse particularly in relation to their understanding of their own history. Following Johnson, we look at the play of agency, intention and responsibility evident in the accounts offered for the collapse. Through that we seek to highlight how these accounts, even when highly critical of Icelandic political and cultural practices, tend to allow for and even encourage the on-going identification with the nation-form.

Key words: history, culture, rhetoric, nation-form, identification

\section{Introduction}

Iceland's threat to default on its debt to Britain should surprise no one. Icelanders are, by nature, intrinsically unreasonable. It is part of their charm and the secret of their survival. If the founders of that unique nation - Norwegians, escaping from medieval tyranny, with their Irish and Scottish slaves and women they kidnapped during their flight - had made a rational appraisal of their prospects, they would not have settled on a giant lump of lava in the cold ocean just south of the Arctic Circle. The national genetic records are precise. The men and women who want to repudiate the obligation to repay the loan are directly descended from the heroes of the sagas. When those marauding old Norsemen found that they had mistaken

University of Iceland.

2 University of Iceland.

3 University of Aberdeen; arnar.arnason@abdn.ac.uk. 
Venice for Constantinople, they sacked it anyway because sacking was their business. Their progeny are not going to feel many qualms about keeping $£ 3.6$ billion of somebody else's money.

Thus Roy Hattersley, former minister and deputy leader of the British Labour Party, arguably better known now as his Spitting Image, writing in "The Times" on January the $8^{\text {th }}$ 2010. Mr Hattersley was writing on the issue of the Icesave debt: money allegedly owed by the Icelandic government to the British because the latter had paid out guarantee on the accounts of British customers of an Icelandic bank that the Icelandic government should, again allegedly, rightly have been responsible for. According to Mr Hattersley, Icelanders seem an unusual nation. They are also the products of their background - in one sentence their genetic make-up, in the next their history. It is only with reference to this background that Icelanders and their current actions can be understood. At the same time that is an adequate and sufficient context to make sense of those actions. The sacking carried out by 'old Norsemen' 1000 years ago explains the refusal of contemporary Icelanders to pay the debt incurred by the activities of a private, if legally Icelandic, bank.

In an interview published early in 2013 in the Icelandic newspaper $D V$, Vigdís Hauksdóttir, a member of Parliament for the Progressive Party (Icelandic: Framsóknarflokkur), claimed that her party's past was irrelevant to its present and its future. Pushed by the journalist to acknowledge the party's complicity in the 'corruption' allegedly widespread in the country in the decades running up to the economic collapse in 2008 - the collapse that brought the Icesave debt along with many other things in its wake - Vigdís answered that the party is only ever its members at any given time. The people who were there before the collapse of 2008, hrunið as it is usually simply referred to in Icelandic, have gone and new people have taken over. The alleged corruption has nothing to do with the people now running the party, the parliamentarian said. The past is immaterial, of no consequence. Commenting on the interview a few days later, the editor of the paper insisted on the importance of analysing, understanding and remembering the history of Iceland, specifically in the years leading up to the collapse. Forgetting the past would be to invite disaster again. History provided a lesson and the means to locate responsibility.

These little episodes, in and of themselves of no particular consequence, serve to highlight the issues we seek to address in this paper. What is at stake when people remember or forget their collective history, their cultural traditions (see Árnason et al. 2003)? What is at issue when the celebration of history is a marked cultural tradition but that history suddenly becomes problematic, not something to celebrate? How does engagement with history speak to the distinction between inside and outside, important in the context of Iceland specifically (Hastrup 1998) but surely more generally too, internal forces and external influences and the dis- 
tribution of agency that is imagined in such formulations? How is the celebration of history evoked in and linked to the attribution of cultural agency?

The context in which we seek to address these questions is Iceland after the banking collapse of the autumn of 2008. Our specific interest is how history has been mobilised to account for and make sense of a very sudden economic collapse. This is particularly significant in this context, we suggest, for two reasons. The celebration of history is a striking feature of Icelandic culture, hugely important in the country's negotiations of its independence politically, economically and culturally, negotiations which are both internal and external to the country itself (see Hastrup 1998; Koester 1990; Árnason et al. 2007). Secondly, the economic collapse can be said to have reversed, or at least problematised significantly, the trajectory that Icelanders had imagined for their own contemporary history as a relatively relentless movement towards an ever brighter future. As such we might suggest that the collapse in Iceland occasioned something akin to mourning in the country as a taken for granted and desired future suddenly seemed lost.

It is of course stating the blindingly obvious to say that anthropologists have long recognised that cultures are historical phenomena. So much has effectively been taken for granted in anthropological thinking on culture since Franz Boas (see Hatch 1974). The recognition that history is cultural, even the possibility to record 'events', for wont of a better word here, as history, is more recent, albeit not so recent any more. What we seek to add to these insights is an insistence that the cultural construction of history can be usefully examined from the perspective of rhetoric. In this we draw on work on rhetoric and culture pursued by anthropologist Michael Carrithers (Carrithers 2009a, 2009b; see Strecker, Tyler 2009). The events leading up to, around and following the collapse in Iceland, the questions that surround them, or perhaps more accurately the answers that people seek to provide to them, we suggest, amount to what Carrithers (2009a: 34) has called items of rhetoric. These are items evoked, mobilised and employed as people seek to convince self and others of the causes of the collapse and the lessons to be learnt from it. To explicate this further, we will discuss culture and rhetoric briefly before moving onto history in Iceland.

\section{Culture and rhetoric}

Carrithers (2009a, 2009b) has argued forcefully that anthropologists should pay serious attention to rhetoric when seeking to understand how people make sense of their past and indeed the future. Moreover, Carrithers maintains that focus on rhetoric is crucial in furthering anthropological analysis and understanding of culture more generally. For Carrithers rhetoric refers to the processes of convincing self and others, for example of the view that Iceland did indeed suffer an economic and moral collapse in autumn 2008. Key here is obviously the attention to convincing as a process, the underlying argument being that this process, aimed at 
both self and others, is a hugely important aspect of social life. An important element of attending to rhetoric, according to Carrithers (2009b), is to acknowledge the directionality of much of human action. Of crucial significance here is the idea of 'addressivity' that Carrithers (2009b: 7) borrows from Mikhail Bakhtin. To speak of addressivity is to highlight the way in which human actions - spoken and unspoken alike - are frequently, if not necessarily always, directed at another person or persons. It might be added that through self-talk such actions are indeed often enough directed at self as well.

This element of addressivity is certainly clearly evident in much of the material that we will present here. In seeking the causes of the collapse in Iceland and in proposing a path to a better future, the material we analyse is clearly addressed to an audience, even as that audience is often enough rather diffuse and mostly imagined rather than physically present. This material, we contend, is clearly intended to affect, to make a movement and lead to a performance, to adjust James Fernandez's phrase slightly (see Carrithers 2009b: 7). It has a rhetorical edge as Carrithers has put it (2009b: 6).

Carrithers (2009b: 3-6) stresses that rhetoric always takes place in a context. That is to say, there is not a universal logic according to which rhetoric operates always and everywhere. Rather, particular tropes, particular metaphors or narratives are particularly powerful within a culture, a term Carrithers uses hesitantly. Culture in this view offers a set of tools that are then put to rhetorical use in the process whereby people seek to convince self or others, and through that to move them to action. We could mention here quickly, for example how the story of having succumbed to foreign rule, and the importance of avoiding that happening again, resonates powerfully with most Icelanders. Or indeed how the trope of foreign exploitation, and again the importance of avoiding that fate, has a rhetorical edge to most people in Iceland. Metaphors drawn from working on sea are also important and powerful as we will have occasion to come back to later.

We wish to draw one further insight from Carrithers' work. In recent years Carrithers (2009a) has explored the theme of collapsing moral orders and their recreation in particular with reference to post-war and then post-unification Germany. Carrithers discusses specifically the importance of overcoming the past (Vergangenheitsbewältigung in German) "as a new item of rhetoric" (2009a: 34) that appeared first in West Germany in the 1950s. This, he adds, is in a global perspective an "unusual understanding of nationalist history" (2009a: 34) - an insight we would like to take a moment to consider. Of course nationalist history, wherever it is found, more commonly celebrates the past and either insists on the present as the logical, inevitable and welcome unfolding of or as a failure to live up to that very past. In the references to 'Old Iceland' and 'New Iceland' in the material we will later analyse, and to the struggle to ensure the victory of the latter over the former, we see a rhetoric similar to the Vergangenheitsbewältigung which Carrithers describes for post-war Germany. 
In what follows we will first discuss the cultural construction of history in Iceland. We then describe the efforts in Iceland to understand the causes of the collapse of 2008. We treat the accounts given as rhetoric, as attempts to convince self and others of a particular view of events. We then describe briefly how these echo in many ways the accounts that were given to explain the rapid economic expansion in Iceland prior to the collapse and the then seemingly boundless prosperity. From that we discuss how attempts to move from the 'Old Iceland' and build a 'New Iceland' draw on these accounts, how the rhetoric is to move to action. We suggest that a certain irony is embedded, as a fundamental aspect of the rhetoric serves to convince people of the continuing identification with the 'nation-form' (Berlant 1998) that was so important in legitimating the politics of economic expansion (see Árnason et al. 2003, 2004).

\section{Methods and ethnographic context}

Over the last ten years we have been engaged in research into changing regimes of death and grief in Iceland. We have carried out extensive fieldwork in the country over that time, conducted numerous interviews and analysed public documents and discussions of relevance to the issues of death and grief. While this experience informs the current work, in this paper we focus mostly on and draw our material from public discussions, and debates in particular, as these have been carried out in the various media forms in Iceland. We have examined newspaper articles and commentaries, comments placed on the internet versions of the same newspapers, radio and television news and debates. Additionally our analysis is informed by our ongoing research experience in Iceland, our participation in everyday discussions about the collapse in particular and state of affairs in Iceland in general.

\section{Culture and history in Iceland}

The anthropological literature on the relationship between culture and history is of course vast and for the most part well beyond the remit of this paper. That the understanding of history is culturally constructed, and hence variable, even that the possibility of understanding the world in terms of history rests on particular cultural assumptions rather than universal conditions, is by now a painfully obvious observation (see Sahlins 1985). It is well established in the ethnographic record that history occupies a hugely important place public life in Iceland (see for example Hastrup 1998; Koester 1990). This is of course not history as a succession of events, but rather structured or plotted history, where particular events take on significance because of their relation to other events preceding or following them; because, that is, of their place in the plot. Thus according to Hastrup, Iceland's history is in public discussions and reflections on the past and the future of the 
'nation', often divided up into three different and distinct periods or epochs. This division in turn has been the basis on which history has been taught in Icelandic schools and as such it is the familiar and unmarked background against which current events in Iceland are often cast (Hastrup 1998: 26).

Following Hastrup (1998: 26) we can say that this story begins with the age of the settlement, generally understood to run roughly from $874 \mathrm{AD}$ to 1262 . This period is frequently presented as a kind of paradise, certainly the golden past of Iceland. During this time the hero Vikings glorified in the Saga, are said to have fled the encroaching tyranny of the King of Norway in order to be able to live freely, an account echoed of course by Mr Hattersley in the excerpt above. This is the time during which Iceland was an independent commonwealth, free and prosperous. This golden past, according to Hastrup, was then lost, like so many Paradises are. The responsibility for this turn of events is variously placed on foreign interference, specifically the desire of the King of Norway to extend his dominion to Iceland, and internal strife as local chieftains fought for supremacy, often enough appealing to said King for assistance. The upshot was that Iceland eventually became part of the Danish realm. The period after this is presented as the 'Dark Ages' (Hastrup 1998: 27) in Iceland. The centuries of Danish rule are generally thought of in Iceland as a time of humiliation and extreme hardship. It is a time when the very future of nation, its language and culture and even its simple physical survival, was seen as being repeatedly in serious danger. The third age of Iceland's history, according to Hastrup, is the post-Independence period. This is the time when paradise has been regained as political sovereignty is seen to lead to cultural and economic prosperity. This is the bright future "seen as a period of progress", to quote Hastrup (1998: 26) again, "of increasing technological sophistication and wealth".

This epoch reached its height in the economic boom in Iceland during the years leading to the collapse, the early 2000s. The period of growth is related to a process known in Iceland as útrás. In ordinary parlance útrás means release of sorts: release for excessive energy, for emotions, needs and desires for example (see Árnason et al. 2004). But here it refers specifically to the foreign economic expansion, if not conquest, of Icelanders. Its opposite, innrás, means invasion, usually meaning military invasion (see also Helgason 2006). During this period, figures of speech such as 'incursion', (strandhögg) 'go Viking', (i víking) and 'gaining ground on foreign shores' (landvinningar) were used widely by politicians, entrepreneurs, the media and others addressing Icelanders' participation in the new global economy (see Ásmundsson et al. 2011). Well known British high street concerns and iconic Danish enterprises were bought by Icelandic businessmen, acquisitions that were spoken of in the terms of Viking raids. The three large Icelandic banks all opened branches outside of Iceland. This process of expansion is central to what Icelanders refer to as útrás.

The útrás of Icelandic businesses was accompanied by speculation and explanation. How was the expansion possible? Where did the money come from? In 
the UK and Denmark rumours of Russian mafia funding were rife, fuelled by the fact that some of the most prominent entrepreneurs made their money initially by brewing ale in St. Petersburg. In Iceland the explanations tended to be congratulatory, celebratory even though it is right to keep in mind here that many of the main media outlets in the country were for some of this time owned by some of the more important business players themselves. The main reason provided for what was seen as spectacular success is contained within the word used to refer to these businessmen: útrásarvíkingar, Vikings of the foreign expansion. This was no mere decoration, as we have already hinted at above. The success of Icelandic businessmen was seen to lie in a characteristic shared with, and perpetuated from the time of, their supposed Viking ancestors, in much the same way as $\mathrm{Mr}$ Hattersley suggested humorously. Quick thinking, decisiveness and courage were abilities attributed to the útrásarvíkingar whose activities were likened to Viking raids (strandhögg), on unsuspecting foreign shores. Of course this was to some extent propaganda promoted by the entrepreneurs themselves through their media outlets. But it was propaganda that had impact, a rhetorical edge because of the cultural context it played upon and in. During fieldwork in the summer of 2007, just over a year before the collapse, people routinely told us that wherever the money might have come from in the first place, these businessmen clearly had qualities for running businesses that set them apart from their foreign colleagues. Such was the success they were evidently having. Official discourse promoted the same ideas. The president of Iceland repeatedly made statements to this effect in his numerous speeches. Thus addressing a history conference in 2006 the president asserted that útrásin had deep roots in the history of the nation. Similarly an official report into the 'Image of Iceland', published in 2008 before the hrun makes similar links. The report makes frequent references to alleged Icelandic qualities of diligence (dugnaður), optimism, (bjartsýni), courage (áræeðni), power (kraftur), and purity (hreinleiki). The report talks about a small nation seeking freedom and independence (frelsisleitlítillarpjóðar) (Icelandic Prime Minister's Office 2008; see also Sagnfræðingafélagið 2008). The report claims further that Icelanders have an indomitable 'can do spirit' and that they tend to be convinced that everything will work out, all treddist as the common Icelandic phrase goes.

While the entrepreneurs themselves, their media outlets, their political supporters and indeed official reports all linked the successes of Icelandic businessmen to particular historically rooted qualities of the Icelandic nation, Porgerður Einarsdóttir (2010) has pointed out that the discourses around the expansion in Iceland were profoundly gendered. Qualities associated with and celebrated as masculine were thus the qualities highlighted as having allowed the economic expansion to take place. Thus while officially the 'whole' nation was being linked to the successes of Icelandic business, the subtext suggested that those successes depended on qualities celebrated in men in particular but not in women.

Other qualities that were emphasized in the report mentioned above, and in the public discourses more generally, as specifically Icelandic was the notion of 
creativity (sköpunargleði) which was often associated to Icelanders' gift of poetry (skáldagáfa). In this context the word athafnaskáld was frequently used. This word has two parts: athafna points to actions, athafnamaður (maður is man) being an entrepreneur. Skáld is a poet. We emphasise that initially athafnaskáld was used very positively to elevate business, or the 'art of business', by associating it with the status of poetry and writing more generally in Iceland, an association that stretches back to the Sagas and the Eddic poetry. Contemporary 'Vikings' were presented as 'poets of útrás' as indicated in the following headline in the influential Icelandic newspaper Morgunblaðið: "The Danish television interviews Icelandic poets of útrás" (December 2, 2005). The connotations of athafnaskáld are maybe somewhat more mixed now as skáldskapur also has the meaning fiction in Icelandic. It turns out, many would now say, that the útrás was skáldskapur from the hopeful start to its bitter finish, a fiction, a fantasy, a deception.

As many have argued (Grétarsdóttir 2010) útrás was routinely portrayed as growing out of the culture, traditions and history of the Icelandic nation. There is of course a clear correspondence between this indigenous view, and Roy Hattersley's analysis. Both rely on a form of essentialism. Here we might ask: what is the implication of this with regards to the indigenous view? What is achieved by such essentialism? First, it is of course a claim that the successes of the útrásarvikingar were the success of the 'nation', that the nation itself was somehow responsible for all of this; the qualities that secured success were qualities of the nation rather than simply the individuals themselves. The extent to which people could relate to the qualities thus portrayed varied widely and we have already noted how gendered the depiction was. However, here we want to highlight another aspect of this portrayal. It is of significance here that two of the banks at the heart of the expansion were owned by the state until the beginning of this century. A rationale for their privatisation was the neo-liberal view that the prosperity of the nation would be best secured through individual initiative and enterprise rather than businesses run by the 'dead hand of the state' as it was often put. The ideology on which privatisation rested in a way removed the stake the nation had in economic development. The discourse around economic expansion may have served to ideologically secure that stake though, establishing a cultural link where and when the political and economic link was being undermined. This is a point to which we will return.

Iceland's inexorable rise, its trajectory to increasing economic prosperity was to be met by furthering the country's political standing. Shortly before the collapse of 2008, Iceland sought a place on the United Nations' Security Council, a clear claim to a place at the centre of the world stage seen as justified in light of economic prowess. It is not surprising then that the economic collapse that followed required extensive and agonising soul searching, attempts to account for what had happened. We turn now to these efforts. 


\section{Worlds collapsing}

The economic meltdown of Iceland in the autumn of 2008 was, after a short period of somewhat panicked bewilderment (see Guðmundur Andri Thorsson in Fréttablaðið, 6.10.2008), swiftly followed by intense efforts to account for and make sense of what had happened. With that, the recent history of the country quickly became subject to sustained scrutiny and debate. The claim was made by many, and denied by others, that accompanying, or more accurately preceding the financial meltdown in the country, had been an even more profound moral, social and political collapse (see for example Geir Rafnsson in Comment is free in "The Guardian" 25.10.2008; Guðmundur Andri Thorsson in "Fréttablaðið" 27.10.2008). Many observed - publicly in print or more privately in speech - that Icelanders had often before faced financial trauma and economic uncertainty either at the hand of the harsh environment in which they live, or the vagaries of the international markets where they sell their produce. Hardship like that, they would add, was nothing new, but rather had been instrumental in making Icelanders who they are. However, what the banking crisis and the wider economic collapse that followed, revealed was a far more troubling coming asunder of the moral, social and political fabric of the country. Indeed, for many commentators the collapse of the moral order was in fact the ultimate cause of the economic crisis. It is not surprising then that effort has been put into understanding the causes of the collapse. This was indeed the conclusion of the Special Investigation Commission, set up by Parliament, into the collapse that reported on the matter in 2010.

While the report of the Special Investigation Commission (SIC) is an important inquiry, its limitations are of particular interest in themselves, as Irma Erlingsdóttir (2011) has noted. Firstly, the period that the Commission examined was quite short, confined as it was to the years immediately before the collapse. That period was hence marked out even here as unusual, as an aberration in the history of the nation more widely. The history of the nation more generally was not called into question, not deemed problematic. Secondly, no attempts were made following the publication of the report to involve Icelanders in general in public discussion about the moral and political collapse and the possible reconciliation to follow it (Erlingsdóttir 2011). The Commission, for good reasons of course, was drawn from a small and narrow group of experts rather than being representative of Icelanders more generally (Erlingsdóttir 2011).

The attempt to locate precisely, examine and understand the causes of the collapse, has in turn fed even more anguished endeavours to rearticulate and rebuild what have been seen as the moral foundations of Icelandic society and the legitimacy of its political order. This has been evidenced, for example, in the protracted, on-going and intensely controversial efforts to rewrite the country's constitution, and in the debates that have taken place around the office of the President and the powers that should properly belong to it. In the effort to rearticulate the moral fabric of the country and re-establish the legitimacy of its politics, references have 
frequently been made to 'Old Iceland', the Iceland of the years leading up to the collapse. These are almost always accompanied by references to the 'New Iceland', the Iceland that is perhaps for most still only a hope, and maybe for many not even a hope anymore, of a better society that will allow more of its members a better life. There has been frequent talk of a struggle, a battle, a war even to bring about the New Iceland. And so, the structure of the New Iceland as a melodrama, a minimal narrative, or a rhetorical device is inherently optimistic - although perhaps it remains to be seen whether that optimism is cruel, in the sense invested in the term by Lauren Berlant (2011).

In the Icelandic periodization of their own history, mentioned above, the events around the changing ages, if that is not too grandiose a way of putting this, take on a particular significance. What was it really that lay behind the settlement of Iceland? Who or what was really responsible for Icelanders agreeing to become subjects of the King of Norway? Who is it that guided the nation to independence and hence is best trusted to secure continuing freedom? We suggest that the events around hruniz, the collapse, and the linguistic forms of 'New Iceland' and 'Old Iceland' have, at least for now, taken on a similar significance in the historical imagination in Iceland. In what follows we discuss the different interpretations that have been put forward in public discussions in Iceland to explain and account for the collapse of the economy and the moral order of Icelandic society in the autumn of 2008. We draw a rough distinction between four different explanations that have been offered. We emphasise how these different accounts draw rhetorically on history.

The collapse as an externally caused natural disaster

During the first week of October 2008 when the Icelandic banking and financial system collapsed it was widely presented domestically as the consequence of external events, the crisis in the global financial system precipitated by the collapse of the Lehman's Brothers Bank. On the $6^{\text {th }}$ of October 2008 "The Guardian" newspaper, for example, described Iceland as being caught in an 'economic storm'. This was also very clearly the line taken by the Icelandic authorities at this time, in particular the then prime minister Geir H. Haarde. This was most clearly expressed in his televised address to the nation on October the $6^{\text {th }} 2008$ which concluded with the quickly infamous words: 'God help Iceland'. The language used in this context was also revealing. The crisis was presented as holskeifla, a huge wave, depicting Iceland as a small boat caught in a storm in the middle of the ocean. This language of course draws on historical references to the simultaneous importance and danger of fishing for the development of Icelandic society. Here rhetorical connotations drawn from Icelandic history are of importance. Unlike most nations Iceland does not have an army and does not celebrate fallen soldiers as national heroes. The heroes of Iceland's struggle for independence were poets and lawyers. The fallen victims of Iceland's struggles for survival and prosperity have 
tended to be fishermen lost at sea. Around their figure has been drawn together both the theme of the struggle of Icelanders in a harsh and dangerous environment (see Brydon 1996: 7) that fishermen in particular face, and the importance of the fishermen's work in securing the prosperity of the nation.

Others referred to the crisis as hamfarir. Hamfarir is a complex word that can carry the meaning of shape shifting. Extension of that meaning is currently most often used to describe an outstanding performance by an athlete. However, the other meaning of the term and the one applicable in this context is of a natural disaster. Thus the phrase náttúruhamfarir (from náttúra nature and hamfarir) is frequently used to talk about such events as volcanic eruptions, hurricanes, avalanches and floods. All are examples of náttúruhamfarir.

What the talk of holskeifla and náttúruhamfarir more generally achieves is clearly that it makes Iceland an innocent victim in the financial crisis. We emphasise again how this works rhetorically because of the enduring power of the story of Icelanders as having long had to cope with and learn to survive in a harsh natural environment. The effect here is that the financial crisis is yet another natural disaster with which Icelanders have long had to deal. The language of natural disaster was accepted by many and was prominent, along with exhortations that "we all have to stand together against this danger", in the first weeks after the collapse. It was rejected by some, for example Steingrímur Sigfússon, the leader of the then opposition Left-Green-Party, who described the collapse as a man-made natural disaster (see "Fréttablaðið" 6.10.2008).

We want to stay with this issue a little bit longer to focus in on the question of intention, agency and responsibility. The prime minister of Iceland in the years before the collapse was Geir H. Haarde, mentioned above. He was also the leader of the Independence Party, Sjálfstreðisflokkur in Icelandic. This is for the most part a relatively broad right wing party, not too different from the British Conservative Party for example, that has emphasised the freedom of the individual and been the leading party in coalition governments in Iceland for most of the country's independence period, including from 1991 until 2009. The emphasis on individual freedom became even more pronounced as the party adopted more neo-liberal politics from 1991 onwards when individual enterprise was championed as the road to economic prosperity for all. A direct and very powerful link was drawn here between individual freedom, agency and responsibility, a link very familiar from Western political and philosophical thought. This was a link that the party emphasised strongly in the run up to parliamentary elections in Iceland in 2007 when it credited the then apparent economic prosperity in Iceland to the wisdom and the actions of its own politicians. This agency and the responsibility that is seen to flow from it is precisely what is being denied as the collapse is presented as a natural disaster.

That politicians claim responsibility for prosperity and deny it for a disaster is perhaps less than surprising news. Something more is going on here though. Following the collapse the Independence Party re-examined its own policies and 
politics. At the party's annual convention following the collapse a motion was passed to reiterate the policies of the party while suggesting that the collapse had been caused by the actions of a few individuals who had abused the economic system to quench their own greed. Thus while the party had, according to this, created the environment within which individuals could exercise their entrepreneurial abilities and aptitudes, the economic catastrophe that followed was caused by the actions of a select few individuals, rather than by the environment itself. The individuals in question, while not named in the declarations of the party's convention, could clearly be identified in a small country, leaving no doubts about who was implicated. They in turn, some of them at least, defended themselves in public. They had not intended harm and because of that not caused the economic collapse. All they had sought to do was to engage in economic activity profitable for themselves and the country as a whole. They, much as anybody, had been caught up in a global recession of which they were victims, not authors.

Barbara Johnson (1994) has written on the play of intention between the individual and the system. She notes (1994: 46-47) how the identification of particular actions as part of misogyny and inequality is almost invariably met by responses that locate these actions as individual, 'private, sophomoric, interpersonally regrettable, and isolated' (1994: 46). That is, what critics point to as systematic and institutional is translated into the regrettable individual actions of people who either meant no harm because harm was not what they intended (Johnson 1994: 47), or are 'a few bad apples', as the phrase goes, not representative of the institution as a whole. To mean something here is to intend it, to hold it as a conscious deliberate intention. Jokes may be told that play on gender stereotypes but intend no harm and as they intend no harm cannot be construed as misogyny. This of course assumes that individuals ordinarily have full control over their actions, that they author or intend them, and would seem to suggest that people can only be held responsible for the actions they fully intend. If a joke I tell to be funny causes harm but it had not been my intention in telling the joke to cause harm, then I should not be held responsible for that harm. Johnson (1994: 46-47) notes that the 'resistance to recognizing misogyny as institutional is the same resistance as the resistance to questioning individual intention and control in language.' This captures accurately how a political party that has claimed institutional responsibility for prosperity through its extending the reach of individual agency and responsibility, in turn seeks to deny individual agency - the collapse was caused by external 'natural events' - or to locate that agency and responsibility with a few 'bad apples', individuals not representative of the party itself.

This play of intention, action and responsibility is clear in how both The Independence Party and the individual entrepreneurs sought to account for their relationship with and responsibility for the economic collapse in Iceland. Such a play is further evident in the second explanation we describe. 
The collapse as caused by British and other foreign actions against Iceland

Soon after the collapse another interpretation gained ground, an interpretation that does not necessarily go entirely against the first one, an interpretation that has since resurfaced around the issue of Icesave and the possible entry of Iceland in the European Union. According to this account the actions of the British government that caused the hrun, or at least made it much worse than it otherwise would have been. The particular actions in question relate to the freezing of Icelandic assets in the UK immediately following the collapse of the three Icelandic banks (see, for example, "The Independent" 9.10.2008; "Morgunblaðið” 22.10.2008). It was claimed, for example, by a number of commentators in Iceland, some of whom had the vested interest of having been involved in the running of the bank, that this had led directly to the collapse of the largest of the Icelandic banks, Kaupping, which otherwise would have survived.

The freezing of Icelandic assets in Britain was widely condemned in Iceland. It was seen as a grave betrayal of what was supposedly a 'friendly nation'. What riled in particular was the use here of British legislation aimed primarily, but not exclusively, at targeting funding for terrorist activities ("Morgunblaðið" 22.10.2008). This portrayal struck a chord with people in Iceland who took to the internet in great numbers to seemingly playfully attempt to convince Gordon Brown and Alastair Darling of their innocence of any involvement with terrorism (see "Fréttablaðið" 22.10.2008). Many of the photographs posted displayed blond and blue eyed Icelanders and were accompanied by a rhetorical question: "Mr Brown, do I look like a terrorist?" The likely unintended but very clear undertone is of course deeply racist, that terrorists look different from us. More recently the President of Iceland has sought to turn the tables on the previous British Government by claiming that it was Mr Brown himself, rather than Icelanders, who was the terrorist, having committed an act of financial terrorism against the Icelandic nation (see http://www.visir.is/-ummaeli-gordon-brown-voru-fjarmalalegt-hrydjuverk-/article/2013131219000).

In the initial discussions regarding British involvement in the hrun, some suggested that in this Britain sought revenge for the cod wars of the twentieth century. Others interpreted British actions as attempted imperial domination and colonial exploitation, re-evoking of course a period of Icelandic history that still resonates powerfully even if the colonial master was a different one. This interpretation came to the fore in the intense debates around the Icesave debt and the question of whether Iceland had to pay that debt. While Mr Hattersley somewhat jokingly sees the resistance to pay as another case of age old Viking thievery, many in Iceland expressed the notion that they were being unfairly bullied by a former world power still blinded by its prior position in the world. In these accounts where responsibility for Iceland's misfortune is placed at foreign doors, agency and responsibility is being located outside of Iceland. Again Iceland is depicted here essentially as a victim, perhaps not of natural disasters but rather of the 
harmful intentions of others, even as remarkably little reflection was offered on how people of such endeavour and courage, as they had been depicted in celebrations of útrásin, could suddenly become such hapless victims.

However, as time passed the interpretations of the causes of the collapse in Iceland increasingly started to point towards private, albeit Icelandic, bankers as the culprits. That is, the interpretation in this context was that Icelandic bankers might be at fault but that they were at fault as individuals rather than as representatives of the Iceland nation, which should then not have to foot the bill. Many accounts along this line were at odds with the previous emphasis on the nationality of the bankers before the hrun, when considerable effort was made by many, the President of Iceland not least, to explain their then apparent success with reference to their specifically Icelandic qualities, often portrayed as existing as unbroken chain of qualities from the Viking era, as we have already discussed.

Losing touch with real valuables as the cause of the collapse, losing touch with Icelandic values as the cause of the collapse

Some commentators in Iceland, and indeed individuals in private discussions, placed the blame for the collapse, at least partly, with the move away from what they would describe as the 'real' economy in Iceland. The influential commentator Guðmundur Andri Thorsson noted for example in one of his regular columns in "Fréttablaðið", that the seeds of the collapse were sown the moment the production of real valuables gave way to speculation in intangibles. When fishing quotas, the right to fish in other words, became more valuable than the fish caught or the ships used to catch them, Icelanders lost sight of the real valuables of economic production and lost themselves in speculation. Implicit, and indeed sometimes explicit, in this interpretation was the suggestion that the hard work of farming and fishing was somehow linked to the essence of what it is to be Icelandic and that this connection had been lost. This echoes earlier fears, discussed for example by Inga Dóra Björnsdóttir (1989), about the disappearance of distinctive Icelandic identity through participation in global economic and political processes. The teaching of economics and business at the University of Iceland was in some cases singled out here as responsible for having further fostered this turn towards speculation.

Other commentators claimed that Icelanders had not so much lost sight of real valuables and their production, but rather real Icelandic values. Thus the rapid economic expansion before the collapse was said to have undermined fundamentally the sense and value of equality and egalitarianism that had previously characterised Icelandic society. Others emphasised the ideal of cooperation that had been lost in the profound individualisation of worth they saw as having accompanied the neo-liberalisation of the Icelandic economy, politics and indeed society since 1991. Still others spoke about how a certain traditional Icelandic down-to-earthness had been replaced by exaggerated and exuberant ostentatious- 
ness. Examples would be taken of previous generations when the ideal had been the creation rather than the showing off of wealth.

\section{Greed and corruption as the cause of the collapse}

Even so, gradually the most powerful interpretation of events was the one that emphasised greed and corruption as the main causes of the collapse of the Icelandic economy. In this view, then, a moral collapse in Iceland predated and precipitated the economic collapse. This remains a powerful interpretation although it is clearly and understandably debated. In the still intensely party political - in the most ordinary sense of that phrase -the future is very much being decided by the writing of the history of the collapse. It varies here somewhat who precisely is termed greedy. In some accounts it is primarily the bankers and other businessmen who amassed vast fortunes that to many now appear entirely ill gotten. That is, driven by greed and devoid of the business acumen they were previously celebrated for, these businessmen amassed their wealth through deception and thievery, effectively robbing the banks from the inside. In other accounts politicians and the occasional public servant are included in this depiction. Politicians stand accused of receiving financial support to feed their political ambitions and the interests of their parties from the very businesses that have been denounced for their greed and corruption. Public servants stand accused, and in one case have been convicted, of using their inside knowledge of the state of the banking system for personal gain. On some occasions commentators seek to stress the complicity of the Icelandic nation in this. The general public was more than happy to participate in the 'party' during the financial boom, borrowing money when money was cheap to spend on what must essentially be regarded as luxuries, some say. Again, the emphasis here is on how a much more fundamental moral collapse led to an economic meltdown. The charge of corruption is in some ways even more profound. Thus many commentators, most famously perhaps former newspaper editor and influential member of the Independence Party, Styrmir Gunnarsson, have claimed that corruption was the root cause of the collapse. The sources of what happened were moral, social and political rather than economic.

Fundamentally the corruption is understood as involving the unhealthy bed sharing of politics, business and public service. Examples are given of favours extended to particular businesses or even particular businessmen, for instance the decisions made in selling the two privatised national banks in 2003. The case has been made by some that in many instances deals were essentially done within The Independence Party and the Progressive Party that tend to include key members government, business and bureaucracy within their folds. In this way commentators would sometimes single out a specific kind of political corruption, that here was a case of dirty deals being done to benefit a chosen few in a way known through cases of political corruption everywhere. In this interpretation, politicians and, in too many cases public servants also, are suspected of acting to further their 
own individual (or at best some other special) interests. Others sought to place the phenomenon more firmly within the particulars of Icelandic society, pointing out the difficulty of avoiding a certain amount of bed sharing in a small society where everyone knows everyone, as the somewhat exaggerated claim goes. Rather than the problem being the corrupt dealings between members of a political party, the unease here centres around the difficulty of ensuring proper process when the key participants are childhood friends, kin, neighbours, sporting team mates, university buddies or some combination of all these. Perhaps this latter worry fuelled the calls and the compulsion for ethical guidelines to be established to govern and guide conduct in numerous different walks of life in Iceland, calls that were loud and clear in the immediate aftermath of the collapse but have perhaps become less vocal since then.

\section{Conclusion: the rhetoric of New Iceland, Old Iceland}

When work on this paper started it appeared that the moral and political collapse of Icelandic society had been largely accepted as the interpretation of events. In the time that the paper has been in writing this has somewhat changed. Rhetoric which claims that the collapse was, in effect, the work of a few rogue individuals is back in vogue although it remains hugely contested. To these claims it is frequently added that the problems have been exacerbated in large part by the inept efforts of the government that came to power after the collapse, a government that some depict as having been all too willing to place foreign interests higher than Icelandic ones. Claims of betrayal, of treachery, have surfaced in relation to Iceland's application to join the European Union. These claims echo through the historical connection, rhetorically achieved, with the subjection to the King of Norway in 1262. As we write, Icelanders are stuck in an extremely protracted and controversial process of adopting a new constitution, a process that now in fact seems to have come to a halt. The new constitution is seen by its supporters as the necessary and minimum requirement for the establishment of a 'New Iceland' that the collapse called for. A new constitution was the key demand by the protestors who drove the government that presided over the collapse from office in early 2009. Following the appointment of a new government extensive work was carried out to write a new constitution. Dedicated attempts were made to move that process out of the hands of politicians and involve the 'nation' in that process. Thus a 'national gathering', Pjóðfundur, was called as key step in that process. Pjóðfundur, simply as a term, has deep echoes from the Icelandic struggle for independence and helped feed the optimism about 'New Iceland' that a new constitution was to help bring into being. However the making of new constitution was effectively blocked by the opposition in Parliament and thus Iceland still has the constitution that many saw as deeply compromised by the collapse.

The optimism around the construction of New Iceland that many felt following the collapse has perhaps not turned out to be cruel, but has certainly largely 
faded. Rhetorical evocation of history has achieved the distribution of agency and responsibilities in such a way that increasingly people seem to accept that the collapse was caused by foreign forces and individual greed. That there was anything systematically wrong in Iceland is an account increasingly under attack. This has been achieved rhetorically by links with Icelandic history, and by the rendering of agency as individual intention.

In this paper we have suggested two things. We have argued that the cultural construction of history is essential in understanding how people in Iceland have sought to make sense of the collapse of 2008. These accounts, we have argued, are informed by how history is culturally structured in Iceland. The collapse took on the significance it had, we have suggested, of course because of the economic impact it had on people's lives, but also because of how it fundamentally problematized the trajectory of history Icelanders had imagined for themselves and their country. The inexorable march to progress, economic, cultural and political, that had been tied to independence, and that the spectacular economic growth in the years before the collapse had seemed to reinforce, was suddenly reversed sharply. Second, we have suggested that the idea of rhetoric is helpful in understanding how people make sense of and account for their history. That accounting, we suggest following Carrithers, has to do with convincing self and others because history is so often fundamentally tied to people's projections of the future. What the rhetorical evocation of history has achieved, we have argued, is to allocate responsibility either to external forces outside the control of Iceland and Icelanders, or to locate them to specific rogue individuals. The possibility that Icelandic history more broadly than simply the years running up to the collapse, might be suspect is dismissed. The idea that there was something systematically deficient in the country is effectively dismissed too. By this the continuing and celebratory identification with the 'nation-form' (Berlant 1998) is secured, drawing on the very same rhetorically structured narratives as were mobilised to celebrate the economic expansion in the first place.

Bibliography

Árnason A., Hafsteinsson S.B., Grétarsdóttir T., 2003, Letters to the Dead. Obituaries and Identity, Memory and Forgetting in Iceland, "Mortality" 8(3).

Árnason A., Hafsteinsson S.B., Grétarsdóttir T., 2004, New Dawn: Death, Grief and the 'Nation-form' in Iceland, "Mortality" 9(4).

Árnason A., Hafsteinsson S.B., Grétarsdóttir T., 2007, Acceleration Nation: Speed, Death and Technologies of Patriotism, "Culture, Theory \& Critique" 48(2).

Ásmundsson Á., Lárusson H., Grétarsdóttir T., 2011, Koddu [catalogue], Reykjavík: The Living Art Museum.

Berlant L., 1998, Live Sex Acts [parental advisory: explicit material], in: N.B. Dirks (ed.), In Near Ruins: Cultural Theory at the End of the Century, London: University of Minnesota Press. 
Berlant L., 2011, Cruel Optimism, Durham: Duke University Press.

Björnsdóttir I.D., 1989, Public View and Private Voices, in: E.P. Durrenberger, G. Pálsson (eds.), The Anthropology of Iceland, Iowa: Iowa University Press.

Brydon A., 1996, Whale-siting: Spatiality in Icelandic Nationalism, in: G. Pálsson, E.P. Durrenberger (eds.), Images of Contemporary Iceland: Everyday Lives and Global Context, Iowa: Iowa University Press.

Carrithers M., 2009a, Story Seeds and the Inchoate, in: M. Carrithers (ed.), Culture, Rhetoric, and the Vicissitudes of Life, Oxford: Berghahn Books.

Carrithers M., 2009b, Introduction, in: M. Carrithers (ed.), Culture, Rhetoric, and the Vicissitudes of Life, Oxford: Berghahn Books.

Einarsdóttir P., 2010, Kynjamyndir og kyngervi nýfrjálshyggjunnar, in: K. Stefánsson (ed.), Eilífðarvélin - Uppgjör við nýfrjálshyggjuna. Reykjavík: University of Iceland Press.

Erlingsdóttir I., 2011, A Weak Force: The Role and Responsibility of the University, "Ritið" 1.

Grétarsdóttir T., 2010, Between Museums: 'Conquering' with Art(work), "Ritið” 1.

Hastrup K., 1998, A Place Apart. An Anthropological Study of the Icelandic World, Oxford: Claredon Press.

Hatch E., 1974, Theories of Man and Culture, New York: Columbia University Press.

Helgason J.K., 2006, Víkingar efnisins, “Morgunblaðið, Lesbók” November 11.

Icelandic Prime Minister's Office, 2008, ÍmyndÍslands, Styrkurstaðaogstefna. Skýrslanefndar. Reykjavik: Prime Ministry.

Johnson B., 1994, The Wake of Deconstruction, Oxford: Blackwell.

Koester D., 1990, Historical Consciousness in Iceland [unpublished PhD thesis], Department of Anthropology, University of Chicago.

Sagnfræðingafélagið, 2008, Imynd Íslands - bréf til forsœetisráðherra, http://www.sagnfraedingafelag.net/page/19/.

Sahlins M., 1985, Islands of History, Chicago: University of Chicago Press.

Strecker I., Tyler S. (eds.), 2009, Culture \& Rhetoric, Oxford: Berghahn. 